\title{
Comparative efficacy and phytotoxicity evaluation of biopesticides, insecticides and Neem formulation against leaf folder (Cnaphlocrocis medinalis guenee) on paddy
}

UPESH KUMAR

Krishi Vigyan Kendra, PATAN (GUJARAT) INDIA

\section{ARITCLE INFO}

Received : 11.12 .2016

Revised : 23.02 .2017

Accepted : 28.02 .2017

\section{KEY WORDS :}

Beaubaria bassiana, Bioefficacy, Phytotoxicity, Paddy

Email : upeshkvk @ gmail.com

\begin{abstract}
Effort were taken to compare the efficacy and phytotoxicity of bioagent B.bassiana Neem formulation and insecticide. Out of six treatment Monocrotophos 36 per cent SL @ $625 \mathrm{ml} / \mathrm{ha}$ and Beauveria bassiana 1.15 per cent WP $\left(1 \times 10^{8} \mathrm{cfu} / \mathrm{g}\right.$ min. $)$ treatments @ 3000 and $2500 \mathrm{~g} / \mathrm{ha}$ were effective to reducing leaf folder larval population on paddy crop and to increase the grain yield. All the treatments were non-phytotoxic to paddy crop and non-toxic to natural enemies in both the year. Beauveria bassiana 1.15 per cent WP applied @ 2500 g/ha dose was optimum to control leaf folder and to increase the yield. Based on the results of bioefficacy and grain yield, use of Beauveria bassiana 1.15 per cent WP @ 2500 g/ha is suggested for the effective management of leaf folder larvae on paddy crop.
\end{abstract}

How to view point the article : Kumar, Upesh (2017). Comparative efficacy and phytotoxicity evaluation of biopesticides, insecticides and Neem formulation against leaf folder (Cnaphlocrocis medinalis guenee) on paddy. Internat. J. Plant Protec., 10(1) : 21-25, DOI : 10.15740/HAS/IJPP/ 10.1/21-25 